\title{
The Anglican Church in Poland
}

\author{
BARTŁOMIEJ H. TOSZEK \\ DR \\ Uniwersytet Szczeciński, Wydział Humanistyczny \\ e-mail: clermont(at)wp.pl
}

Keywords religious policy, religious organizations, Anglicanism, Anglican Church

Abstract The Anglican community in Poland is one of the smallest and slowest developing religious organizations. The article shows historical and present, social, religious and legal determinants, crucial for sluggisg growth of 'Polish' Anglicans number.

\section{Kościół anglikański w Polsce}

Słowa kluczowe polityka wyznaniowa, związki wyznaniowe, anglikanizm, Kościół anglikański

Abstrakt Wspólnota anglikańska w Polsce należy do najmniejszych i najsłabiej rozwijających się związków wyznaniowych. W artykule przedstawiono historyczne, a także współczesne uwarunkowania o charakterze społecznym, religijnym i prawnym mające kluczowe znaczenie dla powolnego wzrostu liczby „polskich” anglikanów.

The factors having influence on the Anglican community in Poland development are based on historical backgrounds as well as closely connected with nowadays conditions. By using social sciences methods (such as macrosystemic, institutional and legal analysis) author presents the Anglicans in Poland history and their modern situation in social, religious and legal dimension.

\section{Historical determinants}

First Anglican clergymen came into Poland at the turn of $16^{\text {th }}$ and $17^{\text {th }} \mathrm{c}$. However they were not missionars, because (from the very beginning of it's existence) the Church of England recognized Catholic's ritual and did not try to replace it by Anglican ceremonies. That was why an Anglican priest's attention was directed only to Royal clerks and mercantile companies' representatives from England and Scotland who constantly or periodically resided in Poland. In the same 
time (because of lively trade relations between northern Polish province of Royal Prussia and South and East England) new chapels for Anglican merchants in Gdańsk and Elbląg were built.

Quick development of small Anglican community in Poland followed at the beginning of $19^{\text {th }} \mathrm{c}$. when priests of this denomination started to interest in possibilities of Jewish people's evangelization. The British and Foreign Bible Society and the Church's Ministry among Jewish People were established in Warszawa in 1816 and 1821 (Towarzystwo Biblijne, 2016). The second of these organizations opened its local branches in Częstochowa, Kalisz, Kielce, Lublin, Piotrków Trybunalski, Poznań and Radom in the next 30 years (Bojanowski, 2015, p. 7). About 300 Jews were baptized in these places as the Anglicans. That activity ended with outbreak of Crimean War (1854) which forced all British citizens (including Anglican clergymen) to leave the Russian Empire and caused Anglican mission's property confiscation. Such repressions were not implemented on Polish territories under Prussian (and then German) as well as Austro-Hungarian rules, where evangelical mission among Jews was continued without any barriers. Growing number of conversions on Gdańsk Pomerania and Greater Poland provinces induced the Church of England to create the first parish on former territory of Polish Kingdom (i.e. Gdańsk) in 1867. Anglicans returned to the part of Poland under Russian rules eight years later. Their evangelization activity resulted in new 345 conversions of Jews till the end of $19^{\text {th }}$ c. (Donnelly, 2016). In consequence almost all members of Anglican community in Poland (especially all clergymen) during Prussian (then German), Austrian (then Austro-Hungarian) and Russian occupation (1795-1918) as well as between $1^{\text {st }}$ and $2^{\text {nd }}$ World War derived from the same social background. However conversion made 'Polish' Anglicans pariahs in Jewish society (which often meant also source of incomes' loss), they were still unable to complex assimilate with Polish because of ethnic (as foreign element) and religious (as non-Catholic). That was why peculiar communes of Jewish proselytes grew up near Anglican missions (in territorial aspect). These people derived subsidies or other forms of aid and were employed in missions as nurses, bakers, printers, gardeners etc.

With the end of WW1 the Anglican mission in Poland was elevated to the parish status with missions in Warszawa and Białystok and with local branches on territories of nowadays Poland and Belarus (Zieliński, 2004, p. 96). In both these cities palatial religious facilities with chapels, printing offices, eating places and surgeries were built (Wiśniewski, 2013, p. 118). Moreover there were land properties bought in 1920s to build even bigger sanctuary for systematically growing Anglican community. Despite of living activity in religious and social sphere, the Anglican Church was not official recognized by the Polish Authorities in mid-war period. It's businesses before governmental and self-governmental administration, civil courts, other public institutions, social organizations and private individuals represented (as well as in cases of many other Protestant communities) the Polish Reformed Church.

After outbreak of the WW2 most of Anglican clergymen with Jewish roots from territories occupied by Germany were sent to ghettos and then murdered in extermination camps (mainly in Treblinka). Chapel in Warszawa was badly damaged during air raid in the first days of September, 1939. The ruins were finally dismantled under decision the Office for the Reconstruction 
of the Capital in 1945. Meanwhile Białystok mission continued it's mission despite of Soviet occupation of east parts Poland. It was definitely closed in early spring of 1940. Till the end of the WW2 almost all members of Anglican community died and only few escaped to neutral countries (Donnelly, 2016).

Renewal of the Anglican Church activity in shape of mid-war period turned out to be impossible after 1945 not only because of reasons described above but also (or rather first of all) of reluctant attitude of the Communist Authorities of Poland. Through the next 46 years pastoral care over small group of Anglicans in Poland (mostly employees of diplomatic posts and merchant missions of Anglo-Saxon countries) was performed by clergymen from city of Hamm in West Germany. They temporarily held services in the seat of the British Embassy in Warszawa.

Political system transformation opened new dialogue perspectives between Polish state and non-Catholic religious communities at the turn of 1980s and 1990s. In result the Anglican Chaplaincy Emmanuel in Warszawa was elevated to the status of unassisted religious organization. Services were moved to the British School in 1991. Since 1996 services have been held regularly (each Sunday) in the Church of the Immaculate Conception of the Most Holiness Virgin Mary (so-called chapel Res Sacra Miser) thanks to courtesy of the Catholic Church (Donnelly, 2016). Anglican mission in Poland became parish again in 2014.

The Anglican Church during it's over 400 year's presence in Poland never tried to compete with dominant religions, i.e. Catholicism and Orthodoxy. The main reason was that Anglican believers were almost all foreigners (mainly English and then British) who only temporarily resided in Poland. Since the beginning of $19^{\text {th }} \mathrm{c}$. the biggest group of Polish Anglicans were Jews, who took away from its native society the sense of difference in opposite to the main element of Polish nation (in ethnic, social and cultural dimension). Charitable and educational operations of Anglican community were also side-lined by the Catholic Church's wider activity in both these spheres. Despite of that 'Polish' Anglicanism enhanced itself systematically by broadening geographical range of Warszawa and Białystok missions' activity in the second part of $19^{\text {th }} \mathrm{c}$. and a lot of evangelical and charitable undertakings in mid-war period. However death of many Anglicans between 1939 and 1945 caused marginalization of the Anglican Church. New perspectives of normal development have been opened only in 1990s. But the lack of possibilities of elaborating steady position in Polish society for last two decades has been one of the biggest and the most visible problem of Anglicanism in Poland.

\section{Present social and religious determinations}

Modern Anglican community in Poland represents 'people from many countries with a multitude of customs, all joining together in worship and song' (Blunt, 2016). In fact people who went to Anglican ceremonies were mostly 'English and Americans living in Poland and working in diplomatic offices, international corporations' bureaus and English teachers' (LibiszowskaŻółtkowska, 2001, p. 55) at the beginning of $21^{\text {st }}$ c. The community involved people 'from a wide variety of countries: Poland, USA, Nigeria, UK, Australia, China (...) and from many 
different professions including business and teaching' (Church of England, 2016) in the next few years. However it is still very small group of believers (about 30-40) (ekumenizm.wiara.pl, 2006) in parish of Warszawa and missions in Gdańsk (closed in 2003) (GUS, 2013, p. 157) and Kraków (harking back to the Anglican mission existing in the same place in 1920s and 1930s). In addition in Anglican ceremonies participate members of other Protestant churches and religious organizations, encouraging by English-language liturgy and liberal approach to communion (without compulsory personal confession).

Although in Anglican liturgy a lot of common things with Catholic rite can be finding, there are no visible links between Anglicanism and Polish tradition (shaped in religious dimension and in almost all parts of Poland by Catholic Church teaching). This problems as well as prosaic question of English-language liturgy make Anglicanism incomprehensive and strange for the most of Polish people. In result Anglican community is often treated (by those who know about it's existence in Poland) as an exclusive club of people coming from Anglo-Saxon (especially British and American) cultural sphere, who reside in Poland only from time to time and whose motivation to assimilate with Polish culture is almost none. In such context the Anglican Church's position is much weaker than other Protestant churches and religious organizations operating in some regions of Poland on historical bases as e.g. in Silesia or Masuria. Out of touch with tradition contributed to indissolution of Polishness and Catholicism (at least in historical dimension) is the next determinant of development (or rather lack of development) of Anglicanism in Poland.

\section{Present legal determinations}

The Article 25 of the Constitution of the Polish Republic of 1997 states that relations between state and churches and other religious organisations based on the rules of 'equal rights (...) and respect for their autonomy and the mutual independence of each in its own sphere, as well as on the principle of cooperation for the individual and the common good' (Konstytucja RP, 1997, Art. 25). Moreover the same article commits public authorities to impartiality in matters of personal conviction, whether religious or philosophical and to ensure freedom of expression such conviction within public life. In constitutional catalogue of personal freedoms and rights is also included guarantee of the freedom of conscience and religion connected with:

freedom to profess or to accept a religion by personal choice as well as to manifest such religion, (...) individually or collectively, publicly or privately by worshipping, praying, participating in ceremonies, performing of rites or teaching. Freedom of religion shall also include possession of sanctuaries and other places of worship (...) as well as the right of individuals, wherever they may be, to benefit religious services (Konstytucja RP, 1997, art. 53).

Churches and other religious organization recognized by the state (this status has been owed by Anglican Church in Poland since 1996) have rights to teach their religious and moral convictions in public schools. 
General guarantees of churches and other religious organizations' activity freedom in the Constitution of the Republic of Poland are précised in the Freedom of Conscience and Conviction Guarantees Act 1989 (Ustawa, 1989). It states that churches and other religious organizations have rights to realize its' aims by:

a) shaping own doctrine, dogmas, rules of faith and liturgy;

b) public worshipping;

c) religious servicing;

d) organizing ceremonies and religious round-ups;

e) managing its' own matters on the grounds of own rules and free exercising of religious power over clergymen and believers;

f) establishing, teaching and employing of clergymen;

g) pursuing sacral investments and other ecclesiastical investments;

h) buying, possessing and selling of chattels and estates and managing them;

i) accumulating fees, obtaining donations, inheritances and other benefits;

j) producing, buying and using products and articles for worshipping and religious practices;

k) teaching and promulgating religion (e.g. in press, books, other papers, films and audiovisual media);

1) possessing, establishing, managing and widening own cemeteries;

m) presenting themselves in public and commercial mass-media;

n) operating own educational care centres;

o) creating and conducting orders and deaconries;

p) creating organisations acting for religious formation, public worshipping and counteracting social pathologies and its results;

q) operating a charitable and care actions;

r) creating interecclesiastical organizations;

s) affiliating with international religious and interreligious organizations (Ustawa, 1989, art. 19-19a).

Regulations of the Freedom of Conscience and Conviction Guarantees Act concern also registration of churches and other religious organizations rules and the way of acting in property matters (claimed till the end of 1998) of these subjects (particularly in questions of reprivatisation).

Churches and other religious organizations have guaranteed on the grounds of the Constitution of the Republic of Poland and the Freedom of Conscience and Conviction Guarantees Act possibilities to realize almost all undertakings in customarily understanding religiousness (as shaping certain religious formation by teaching in sanctuaries, imposing on believers certain duties in private and public life, public manifesting of religious convictions and realising missionary vocation in the frames of civil law and rules of social coexistence). Churches and other religious organizations can also undertake a lot of social (non-religious) operations, e.g. continuous and periodic charity and care actions (not only for the members of its' own communities), establishing and managing its' own mass-media and printing offices etc. In this way all recognized by the 
state (i.e. included in the register of churches and other religious organizations) religious communities (according to the will of Polish lawmaker as showed in the preamble of the Freedom of Conscience and Conviction Guarantees Act) have possibility to take part 'in development of national culture and enhancing primary moral values' (Ustawa, 1989, preamble). This applies also to Anglicans (as registered religious community) who can freely and independently (i.e. directly) shaping their relations with public institutions, social organizations and private individuals.

The main act of internal law of Anglican community in Poland is the Statute. This document stated that 'the Anglican Church in Poland is part of the Church of England and belongs to the Diocese of Gibraltar' (Borecki, Janik, 2012, p. 445) involving all continental Europe (Diocese in Europe, 2016). Bishop of Gibraltar powers are the same as other diocesan bishops according to the rules and customs in the Anglican Church including especially: establishing and withdrawing parsons in each parish (or those who have powers of parsons); creating, abolishing and changing parishes, making decisions about moving parts of properties and incomes of existing parishes to the new parish; making decisions about allocation of abolishing parish property; changing the Statute of Anglican community in Poland and abolishing of this community (with deciding about allocation of it's property). The main aim of 'Polish' Anglican Church is:

preaching of pure World of God and sacraments' resolving (...). To realise this aim, the Church:

1) prepares (...) liturgical services, ceremonies, and prayers named in the Book of Common Prayer and other official prayer books of the Anglican Church;

2) organizes meetings, talkings, concerts and other events with religious, moral and educational targets;

3) conducts charitable activity;

4) conducts ecumenical cooperation with other Christian churches in Poland;

5) possess an essential property (Borecki, Janik, 2012, p. 445-446).

All members of Anglican community (i.e. clergymen and believers) are required to live according to orders of faith and morality as well as giving the Church financial assistance and amount of work. Simultaneously they have rights to receive sacraments, participating in liturgical services, ceremonies and prayers as well as in organizing by their community meetings, talkings, concerts and other events with religious, moral and educational targets. Adults (older than 18 years) have rights to participate in parish assemblies (with the right to vote), active and passive electoral rights in parish committee and the Church conference (in case of it's establishing) elections.

Clergy of the only Anglican parish in Poland (in Warszawa) are parson, vicar and diacons. Parson's position has been owed by chaplain rev. David Brown since 2014. He practises not only liturgical, pastoral and sacramental functions but also manages organizational and financial matters of the parish and represents it in external relations (especially with public administration and civil courts). Vicar (rev. Felix Malibu) is not only pastor, but also helps parson in liturgical and sacramental functions as well as in managing of the parish. In turn, diacons can lead prayers, read the word of God, baptize (only in absence of parson and vicar), assist in some ceremonials 
and funerals, teach children and visit ills (Borecki, Janik, 2012, p. 446-447). Above of formal structure (i.e. based on the Statute rules) exists parish's resident (honourable parson) rev. Robert Gamble and visiting priests arriving periodically on the Bishop reccomendations. There is also musical director of the parish (well-known musician Rostisław Wygranienko) who often organizes organ concerts and leads the vocal band 'Anglican Voices of Warszawa' (Wygranienko, 2016). Parson, vicar, diacons and 8-12 believers (elected by parish assembly) establish parish committee representing all members of the community in discussing pastoral, charitable, educational, financial and property matters. According to the Statute of the Anglican Church in Poland 'if more than one parish of the Church would be establish, there will be create Church conference to provide assistance to parson of Warszawa parish' (Borecki, Janik, 2012, p. 448). That organ (comprising 3 delegates of each parish elected for 3 years) have advisory rights (to parson) in pastoral, financial and property matters of the whole Anglican community in Poland.

The Statute constitutes sources of incomes of the Anglican Church in Poland as believer's fees, donations, inheritances, other benefits and revenues of organized jumble sales (parish incomes) as well as financial aid offers by members of the Anglican Churches Community. ${ }^{1}$ The Church and parishes (having separate legal personality) have possibilities to receive on their own chattels and estates from Poland and abroad as donations, inheritances, other benefits; buy, possess, manage and sell properties; rent and fee lands, buildings and locals; envisage and have bank accounts (Borecki, Janik, 2012, p. 451). Responsibility for proper financial and property management is taken by parsons in parishes and parson of the Warszawa parish (being today the only parish with one mission) in the whole Anglican community in Poland.

The Anglican Church in Poland is not limited by own Statute in the range of it's evangelical mission (especially teaching and popularisation of Anglicanism through mass-media) or charitable and care actions to the certain territory as well as to realizing it's mission only among members of Anglican community (which shows e.g. directing of it's cultural initiatives to all Polish people). Moreover, traditional tolerance for the new social trends (e.g. accepting priesthood of women and then allowing them to fill highest positions in the Church of England hierarchy as well as approval of homosexual partnerships by some parts of the Anglican Churches Community)

1 The Anglican Communion includes 38 provincial churches, i.e.: the Anglican Church in Aotearoa, New Zealand and Polynesia; the Anglican Church of Australia; the Church of Bangladesh; Igreja Episcopal Anglicana do Brasil; the Anglican Church of Burundi; the Anglican Church of Canada; the Church of the Province of Central Africa; Iglesia Anglicana de la Region Central de America; Province de l'Eglise Anglicane du Congo; the Church of England; Hong Kong Sheng Kung Hui; the Church of the Province of the Indian Ocean; the Church of Ireland; Nippon Sei Ko Kai (the Anglican Communion in Japan); the Episcopal Church in Jerusalem and the Middle East; the Anglican Church of Kenya; the Anglican Church of Korea; the Anglican Church of Melanesia; La Iglesia Anglicana de Mexico; the Church of the Province of Myanmar (Burma); the Church of Nigeria; the Church of North India (United); the Church of Pakistan; the Anglican Church of Papua New Guinea; the Episcopal Church in the Philippines; Province de l'Eglise Anglicane au Rwanda; the Scottish Episcopal Church; Church of the Province of South East Asia; the Church of South India (United); the Anglican Church of Southern Africa; the Anglican Church of South America; Province of the Episcopal Church of South Sudan and Sudan; the Anglican Church of Tanzania; the Church of the Province of Uganda; the Episcopal Church (USA); the Church in Wales; the Church of the Province of West Africa; the Church in the Province of the West Indies and 6 extra-provincial churches, i.e.: Bermuda, Falkland Islands, the Lusitanian Church, The Reformed Episcopal Church of Spain, the Church of Ceylon and Iglesia Episcopal de Cuba (Anglican Communion, 2016). 
is potential incentive to conversion for the people not identifying or less identifying with other Christian or non-Christian churches which require stricter religious and moral formation. Additionally, English-language religious services, ceremonies and prayers (or in others languages if necessary) (Borecki, Janik, 2012, p. 450) make Anglican community open for foreigners living in Poland and speaking in English. Civil law regulations (on the grounds of the Constitution of the Republic of Poland and the Freedom of Conscience and Conviction Guarantees Act) as well as internal law of the Anglican Church in Poland can be named as steady (without administrative, religious or moral barriers) foundation to realize evangelical mission aimed for systematic growth of the number of believers.

\section{Conclusion}

Anglican's presence in Poland from the beginning of $17^{\text {th }} \mathrm{c}$. was broken in 1939-1940. Anglican community did not recover it's vitality after WW2 and became limited only to small group of foreigners in Poland. It's real development have started in 1990s. That is why Anglican parish of Warszawa (and recreated in the last decade mission in Kraków a fortiori) cannot be named real follower of traditions conceived in Polish Kingdom. In fact only formal registration of the Anglican Church in Poland (placing it among religious organizations having regulated relations with the state) has opened process of shaping the community's final formula, still not ended (which proofs the lack of steady number of Anglican believers living in Poland). Labile and less noticeable presence in the life of Polish nation (caused partially by longstanding building it's structures on the base of Jewish society living on the margin of the main current of the social life) is now the main problem obstructing (or even precluding) visible substantiate of Anglicans' activity in Poland. Because all clergymen and the most of believers (and other participants of Anglican services) are foreigners connected with Protestant circle of tradition, so the Anglican community is de facto not able to create sustainable links between it's rite and Polish tradition (shaped mainly by the Catholic Church influences). In result Anglicanism is still 'foreign' religion which is not in the centre of social interest and unable to attract new converts (except of individual cases). This situation lasts despite of legal conditions conductive to churches and other religious organizations' development guaranteed by the state as well as created by the Anglican Church in Poland inner law and administrative instruments which allow conducting wide evangelical and social activity.

To reasume it must be clear that modern situation of the Anglican Church in Poland is not determined by historical circumstances and only few by legal conditions (equivalent to similar solutions in other secular and democratic countries). Essential for 'Polish' Anglicanism development are social and religious determinations (especially inability to rivalry with Catholicism, lack of roots in Polish tradition and basing the community on almost nothing but foreigners) causing present position of the Anglican Church (in predictable perspective) as tangential element of religious life in Poland. 


\section{References}

Anglican Communion (2016). Member Churches, 30 grudnia. Retrieved from: http://www.anglicancommunion.org/ structures/member-churches.aspx.

Blunt A. (2016). Our Community, 30 grudnia. Retrieved from: http://www.anglicanchurch.pl/about-us/our-community.

Bojanowski, M. (2015). Londyńskie Towarzystwo Krzewienia Chrześcijaństwa wśród Żydów. Chidusz. Magazyn Żydowski, 9 (22), 6-13.

Borecki, P., Janik, C. (wybór i opracowanie) (2012). Prawo wewnętrzne nierzymskokatolickich zwiąków wyznaniowych w Polsce. Wybór aktów prawnych. Warszawa: Dom Wydawniczy Elipsa.

Church of England. Kościół Anglikański w Polsce (2016). Warszawa/Warszawa, 30 grudnia. Retrieved from: http:// www.anglikanie.pl/warszawaWarszawa.

Diocese in Europe (2016). Where we are, 30 grudnia. Pobrano z: http://europe.anglican.org/where-we-are/churchlocations.

Donnelly J. (2016). Our History, 30 grudnia. Retrieved from: http://www.anglicanchurch.pl/about-us/our-history.

Główny Urząd Statystyczny (2013). Wyznania religijne, stowarzyszenia narodowościowe i etniczne w Polsce 20092011. Warszawa: Zakład Wydawnictw Statystycznych.

Konstytucja Rzeczypospolitej Polskiej z 2.04.1997 r. (Dz.U. nr 78, poz. 483 ze zm.).

Kościól anglikański (2016), 30 grudnia. Retrieved from: http://ekumenizm.wiara.pl/doc/478496.Kosciol-anglikanski/4.

Libiszowska-Żółtkowska, M. (2001). Kościoły i związki wyznaniowe w Polsce. Warszawa: Wydawnictwo Księży Werbistów Verbinum.

Towarzystwo Biblijne w Polsce (2016). Towarzystwo Biblijne, 30 grudnia. Retrieved from: http://tb.org.pl/about-2/ towarzystwo-biblijne.

Ustawa z 17.05.1989 r. o gwarancjach wolności sumienia i wyznania (Dz.U. z 2005 r. nr 231, poz. 1965 ze zm.).

Wiśniewski, T. (2013). Nawracanie Żydów na ziemiach polskich. Misja Barbikańska w Białymstoku. Łódź: Dom Wydawniczy Księży Młyn.

Wygranienko, R. (2016). O mnie, 30 grudnia. Retrieved from: http://www.concertorganist.eu/pl/01.html.

Zieliński, T.J. (2004). Schyłek istnienia Misji Barbikańskiej w Białymstoku na tle dziejów brytyjskich misji wśród Żydów na ziemiach polskich. Myśl Protestancka, 1-2 (29-30), 91-114.

\section{Cytowanie}

Toszek, B.H.. (2017). The Anglican Church in Poland. Acta Politica Polonica, 1 (39), 91-99. DOI: 10.18276/ap. 2017.39-08. 
